\title{
Hope in the Context of Climate Change: Jonathan Sacks' Interpretation of the Exodus and Radical Uncertainty
}

\author{
Jan Jorrit Hasselaar \\ Vrije Universiteit Amsterdam, the Amsterdam Centre for Religion and \\ Sustainable Development (Faculty of Religion and Theology) \\ j.j.hasselaar@vu.nl
}

\begin{abstract}
The purpose of this article is to explore an understanding of hope that seeks to bridge the gap between a contemplative and action-oriented approach to hope. The argument is based in particular on an extensive study of the literature concerning the work of Jonathan Sacks. His reading of hope reaches back to the narrative of the Exodus and highlights several key assumptions to do with the principle of radical uncertainty. The intention is to situate these assumptions within the context of climate change. Most notably, Sacks' concept of hope reveals a transformative response to climate change in which people gradually change their identity. For Sacks the key instrument of transformation for both religious and secular is a public Sabbath. An example of such is provided and Sacks' thinking is set alongside the work of some leading theologians.
\end{abstract}

\section{Keywords}

climate change - radical uncertainty - hope - Exodus - Jonathan Sacks

\section{$1 \quad$ Hope}

'How should one respond to climate change, Tata', asks Irene. Tata (Polish for father), the sociologist Zygmunt Bauman answers his daughter that there is 
a response of hope possible. ${ }^{1}$ This remark by Bauman is interesting because the cultural critic Terry Eagleton reckons that hope has been a curiously neglected notion in an age which ... confronts us with "the felt loss of a future".' The French philosopher Pascal Bruckner, likewise, argues that it is not hope, but despair, in the sense of fear and apocalypse, that is widespread with regard to environmental issues, including climate change. ${ }^{3}$ Clive Hamilton, the Australian public intellectual, has written a Requiem for a Species - that species being humankind. It is as if hope has been abandoned.

For Hamilton 'despair is a natural human response to the new reality we face and to resist it is to deny the truth: ${ }^{4}$ But he further argues that it is unhealthy and unhelpful to stop here. 'Emerging from despair means accepting the situation and resuming our equanimity; but if we go no further we risk becoming mired in passivity and fatalism. ${ }^{5}$ Hamilton takes advice from Pablo Casals: 'The situation is hopeless; we must now take the next step'. ${ }^{6} \mathrm{He}$ is willing to concede that 'finding meaning in adverse circumstances is one of the most remarkable human qualities. ${ }^{7}$ Hamilton acknowledges the role of religion and wonders whether abandoning the lesser gods like money, growth and optimism will lead people to turn to the sacred for protection. ${ }^{8}$ What, then, to hope for? ${ }^{9}$

Jürgen Moltmann has long argued that hope is a neglected aspect within theology, in the sense that there are theological traditions on love and faith,

1 Florentijn van Rootselaar, 'De mens kan niet wereldwijd denken', Trouw (15 February 2014), <http://www.trouw.nl/tr/nl/5oog/Archief/article/detail/3597612/2014/o2/15/De-mens -kan-niet-wereldwijd-denken.dhtml> [accessed 27 November 2018].

2 Terry Eagleton, Hope Without Optimism (Charlottesville: University of Virginia Press, 2015), p. xi.

3 Pascal Bruckner, The Fanaticism of the Apocalypse: Save the Earth, Punish Human Beings (Cambridge: Polity Press, 2013), p. 2.

4 Clive Hamilton, Requiem for a Species: Why We Resist the Truth about Climate Change (London \& New York: Routledge, 2015), p. 226.

5 Ibid.

6 Ibid., p. 222.

7 Ibid.

8 Ibid., p. 221.

9 The realization that humanity has become an agent in the constitution of its habitat is described in terms of entering the Anthropocene. I do take note of debates about how to interpret the Anthropocene, as for example expressed in Simon Dalby, 'Framing the Anthropocene: The good, the bad and the ugly', The Anthropocene Review, 3:1 (2016), 33-51. $<$ https://doi.org/10.1177/2053019615618681> These debates deserve more discussion, also in relation to hope, than can be offered in this article. 
but there is no tradition '... shot through by hope'.10 It is true that in recent years some theologians have started to reflect on hope and its relationship to climate change. Albert Nolan, South African Dominican priest and well known for his work against the apartheid system, argues for developing a perspective of hope in this context that is not based on signs, but on trust in God.11 Erik Borgman, a prominent Dutch theologian, has developed a Catholic perspective through his interaction with the encyclical Laudato Si'. He argues for a politics of contemplation in order to find hope where only hopelessness seems to remain. ${ }^{12}$ Within Borgman's notion of contemplation, the emphasis is explictly on the promise of God. Borgman states that looking with eyes of love, the world becomes visible as a place of promise, which she in essence is. ${ }^{13}$ The essence of this perspective is to see where the light of love presents itself, to let it in, and to put oneself in the service of this light. ${ }^{14}$ With his politics of contemplation, Borgman argues against a too activist approach in Dutch policies. In the wake of the Fifth Assesment Report of the Intergovernmental Panel on Climate Change (IPCC), suggesting that exceeding the critical threshold of two degrees Celsius before the end of the century may be unavoidable, Stefan Skrimshire highlights that an attitude of hope 'that denies despair in the face of such epic failures, and encourages action in the face of the death that such failures will bring, may be an extremely welcome one in the light of such a report'.15

The aim of this article is to examine a hopeful answer to climate change that allows for a bridge to cross the gap between contemplative and actionoriented approaches. For this purpose the work of Jonathan Sacks will be used. Sacks has written extensively about hope. ${ }^{16}$

10 Jürgen Moltmann, The Living God and the Fullness of Life (Geneva: World Council of Churches, 2015), p. 177.

11 Albert Nolan, Hope in an Age of Despair (New York: Orbis Books, 2010).

12 Erik Borgman, Leven van wat komt: Een katholiek uitzicht op de samenleving (Utrecht: Uitgeverij Meinema, 2017), p. 102.

13 Ibid., p. 76 .

14 Ibid., p. 35 .

15 Stefan Skrimshire, 'Eschatology', in Michael S. Northcott and Peter M. Scott, eds, Systematic Theology and Climate Change: Ecumenical Perspectives (London: Routledge, 2014), pp. $157-174$ at p. 5.

16 Sacks is former Chief Rabbi of the United Hebrew Congregations of the Commonwealth (1991-2013). He currently serves as the Ingeborg and Ira Rennert Global Distinguished Professor at New York University. 
Climate change itself is too broad to be the focus of this article. The more specific focus is on uncertainty, more especially on radical uncertainty. Within the context of climate change there is not just one uncertainty. Climate change is surrounded by many uncertainties. There is, for example, uncertainty about climate sensitivity. This turn of phrase deals with the relationship between the human-caused emissions and the temperature changes that will result from these emissions. There is also uncertainty about emission scenarios; here lies the pressing concern regarding the future growth, or reduction, of $\mathrm{CO} 2$ emissions. Finally, even if we were able to know accurately, and in detail, how the climate is going to change, we would still not understand fully the implications for social and economic activity. ${ }^{17}$

Uncertainty in the field of climate change is attributed to two main sources by Heal and Millner. ${ }^{18}$ The first source is scientific uncertainty, hence an incomplete understanding of the climate system. The second source of uncertainty is socio-economic uncertainty-that is, an incomplete understanding of the impacts of climate change on people and societies. For the purposes of the argument of this article I am adding a third source of uncertainty, which might best be termed "radical uncertainty". It is a source of uncertainty inherent in what Hannah Arendt has called 'the human condition of existence'. By this designation of what it means to be human she means that her point of departure is lived experience. In the prologue of The Human Condition, Arendt writes: 'What I propose in the following is a reconsideration of the human condition from the vantage point of our newest experiences and our most recent fears. ${ }^{19}$ Using the human condition in this way implies that the future cannot be known in advance and is, therefore, radically uncertain.

Arendt's concept of the human condition is highly relevant for climate change. It is not just a condition underlying human life. She argues that 'men (sic) are conditioned beings because everything they come in contact with turns immediately into a condition of their existence. ${ }^{20}$ In other words, the

\footnotetext{
17 Geoffrey Heal and Bengt Kristöm, 'Uncertainty and Climate change', Environmental and Resource Economics, 22 (2002), 3-39, <http://dx.doi.org/10.2139/ssrn.302399>, [accessed 27 November 2018].

18 Geoffrey Heal and Antony Millner, 'Uncertainty and Decision in Climate Change Economics', (Cambridge: National Bureau of Economic Research, 2013), working Paper 18929, <https://www.nber.org/papers/w18929> [accessed 27 November 2018].

19 Hannah Arendt, The Human Condition (Chicago: The University of Chicago Press, 1958, 1998), p. 5 .

20 Ibid., p. 9.
} 
basic human conditions permeate human life and the choices made by human beings. As a consequence, this source of uncertainty permeates the two other sources of uncertainty: scientific uncertainty and socio-economic uncertainty.

Using the human condition as the point of departure implies that the future is radically uncertain. Sacks argues that there are at least two possibilities for interpreting radical uncertainty, namely tragedy and hope. The former expresses a view of the future in which fate controls human beings. It is not difficult to see how this tragic sense of fate can readily flow from the kind of radical uncertainty that climate change readily projects. Sacks makes the case for a more hopeful interpretation. It is one which stands in a long tradition that goes back to the Hebrew Bible.

\section{$3 \quad$ Narrative}

Sacks repeatedly stresses that in the Hebrew Bible there is a concept of hope based on the narrative of the Exodus. The first question that arises out of this claim is what, then, is meant by a narrative. Sacks reasons that one of the characteristics of the Hebrew Bible is that it conveys a set of truths through narrative. ${ }^{21}$ The reason to use a narrative is that it helps to disclose and explain the human condition. ${ }^{22}$ In a narrative, as in life, one never knows what will happen next. In the biblical narrative human beings are free. As a consequence,

our fate does not lie in the stars, nor in the human genome, or in any other form of determinism. We become what we choose to be. Therefore, we don't know what will happen next ... and the best way of showing this is by way of stories, in all of which the outcome is in doubt. ${ }^{23}$

A special feature of the biblical narrative is that Torah adopts a very specific mode of story-telling, to which Sacks refers as the 'concealed counternarrative'. ${ }^{24}$ It is a term that needs to be explained further. First of all, for the

21 Jonathan Sacks, The Dignity of Difference: How to Avoid the Clash of Civilizations (London/ New York: Continuum International Publishing Group, 2002), p. 5 o.

22 Jonathan Sacks, The Great Partnership: God, Science and the Search for Meaning (London: Hodder \& Stoughton Ltd, 2012), pp. 53-4.

23 Jonathan Sacks, Covenant \& Conversation, Genesis: The Book of Beginnings (Jerusalem/ London: Maggid Books, 2009), p. 8.

24 Jonathan Sacks, Covenant \& Conversation, Leviticus: The Book of Holiness (Jerusalem/ London: Maggid Books, 2015), p. 5 . 
narrative to be 'concealed' means that beneath the surface of each narrative lies another layer of meaning. Its significance can only be grasped by closely reading or listening. Sacks explains:

Our understanding of the book grows as we grow. Each age adds insights, commentaries and interpretations of its own. The book's literary style allows it to be read afresh in each generation. That too tells us something significant about the Torah's view of human knowledge: The truths of the human condition are simply too deep to be understood at once and on the surface. Only stories have this depth, this ambiguity, this principled multiplicity of meanings. ${ }^{25}$

The term 'narrative' attracts the idea of that which is 'counter'. The layer below the surface is not only concealed. It usually also turns out to be radically different from the layer on the surface. The layer under the surface often goes in the opposite direction. Sacks again explains:

The Torah signals this by giving us clues, discrepancies in the text, not obvious enough to be noticed at first glance but sufficient to make the thoughtful reader go back and read the text again and discover that the real story the Torah is telling us is richer and more complex than we first thought. ${ }^{26}$

The Torah thus conveys a set of truths through narrative in order to take seriously the human condition.

\section{Narrative of the Exodus and Its Concept of Hope}

Sacks believes that many readers may think that the narrative of the Exodus is primarily about the divine intervention in history. God can then be seen as an external force or energy that delivers a people from evil or radical uncertainty. Such a reading misses the complete meaning of the narrative, however. Sacks insists that, in order to understand the Exodus, it is critical to delve beneath the surface of the biblical text itself.

25 Sacks, 'Covenant \& Conversation, Genesis', p. 7.

26 Sacks, 'Covenant \& Conversation, Leviticus', p. 5. 
Sacks argues that Exodus contains a number of double narratives, the significance of which only becomes clear by considering them together. ${ }^{27}$ There are two battles, one immediately before, the other immediately after the crossing of the Reed Sea, the first against Pharaoh and his chariots (14:13-14), the second against the Amalekites (17:8-13). There are two sets of stone tablets recording the revelation at Mount Sinai, one before the episode of the Golden Calf (broken by Moses on his descent from the mountain) (20), the second after the people have been forgiven for the Calf (34). There are two times that God is revealed in a cloud of glory, once at Mount Sinai (24:15-18), the other, at the end of Exodus, in the Tabernacle (40:34-35). The Sinai covenant was declared twice, once by God (20:1-14), the second time by Moses, reading from the book of the covenant he had written to record God's words (24:1-11). There are two accounts of the construction of the Tabernacle, one before (25-30), the other (35-40) after the Golden Calf.

Sacks argues that in all these cases, the same shift of responsibility takes place. It is a movement from divine initiative to human endeavour. Exodus tells a double story. The first of the paired episodes tells about an act done by God alone. The second one involves human participation. In the first example the Israelites did not fight against the Egyptians, but they did fight against the Amalekites. In the second example, first Moses was passive, in the second set of stone tablets Moses had shared in the making. In each of the first of the paired episodes it is God who delivers the people by a set of miracles. In each of the second ones people are participating.

Sacks concludes that '[a] people can be granted freedom by an external cause, in this case divine intervention. But a people sustain freedom by their own efforts. It is not what God does for us, but what we do for God, that changes $u s^{\prime 28}$ It follows that a people's identity can only be transformed by the people themselves. For Sacks identity is seen in the images people live by - that is, their images of themselves, others and the world. An external agency can set a people in motion — for example to leave slavery in Egypt—but their identity of being enslaved cannot be changed solely by an external cause. In the longer term, a people must change the images by which they live. This interpretation of the Exodus narrative exposes a concept of hope in which the future of a particular people is not determined by its past. There is the possibility to learn the gradual taking of responsibility for a liberating, but radically uncertain future.

27 Jonathan Sacks, Covenant \& Conversation, Exodus: The Book of Redemption (Jerusalem/ London: Maggid Books, 2010), pp. 14-5.

28 Sacks, 'Covenant \& Conversation, Exodus', p. 15. 
Sacks' reading of hope, derived as it is from the experience of the Exodus, lends itself to several key assumptions to address radical uncertainty. The first has to do with a change of identity. Sacks assumes that there are two kinds of identity in the Exodus. The first is referred to with the Hebrew word am. It is an identity based on a shared history - in this instance, slavery in Egypt. Sacks describes them as a community of fate. Their future is radically uncertain, but Sacks' interpretation of the Exodus allows for the future not to be an ominous void. The second potential form of identity is expressed through the Hebrew word edah. This understanding is one of an identity based on where a people are going to: it is a shared vision of the future that includes all involved. In this case the people are defined by the social order they are called on to create. Sacks identifies this society as a community of faith. In the Exodus, the new identity is expressed in the ten words or principles of the covenant. Even when the people have actively adopted a new identity, the ten words are accompanied by the memory that 'Remember that you were slaves in Egypt'. The reason for this call to remember is to ensure that the covenant remains open and does not become a new, settled, status quo. That openness to a yet-to-be disclosed is evident in the injunction: 'do not harm the stranger because you were once where he is now. See the world from his perspective because it is where your ancestors stood'. ${ }^{29}$

The second of Sacks' key considerations is the need for time. The Exodus is the journey of the Israelites towards the promised land. There is a destination, a free society, a society that will be the opposite of Egypt. For Sacks the emphasis of the story is not on the promised land, but the long journey on the way. It is in this course of their wanderings that the identity of the Israelites slowly changes. Sacks here refers to the twelfth-century Jewish thinker Moses Maimonides and his The Guide of the Perplexed (part III chapter 32) in order to explain the need for time. Maimonides wrote that it is 'impossible to go from one extreme to another'. It takes time to change the human heart and images. It is impossible for the Israelites to suddenly discontinue everything that they have been accustomed to in Egypt. Sacks appropriates Maimonides' assertion that God wanted human beings to abolish slavery, but by their own choice. This is a journey that takes time and the way of this journey is hardly straight. 'There are digressions and diversions, blind alleys and false turnings,

29 Jonathan Sacks, Not in God's Name: Confronting Religious Violence (London: Hodder \& Stoughton, 2015), p. 184. 
backslidings and rebellions'. At times the people despair and long back to go back to a misremembered past, an idealised Egypt, the 'world we have lost'. ${ }^{30}$

The third of Sacks' key criteria is the motivation of chessed. The driving force that leads to the change of identity from am to edah is chessed. ${ }^{31}$ Chessed is the Hebrew word, usually translated as 'kindness' or 'compassion'; in Latin it becomes charitas. For Sacks, chessed is not love as kindness, emotion or passion, but a kind of love that sees oneself and others primarily as valuable in themselves, regardless of one's merits or one's use for others. Chessed considers all people, and therefore not only the Pharaoh, to be made in the image of God. These 'all people' include the neighbour, who is almost like me, and also the stranger, who is completely different from what I am. As a consequence, chessed values plurality among people: it values the dignity of difference. Everyone has to contribute something unique to the shared project of which everyone is part. The construction of a common identity is not separate from or external to societal and economic production, but it is instead integral to and inseparable from it. Chessed is not only about the individual: it is also a societal and economic driving force. The reason for this role lies in how chessed creates new relationships in which new societies can be built. ${ }^{32}$ Chessed alters the perspective of things already seen in a way one has have never noticed. By doing so it contributes to a hopeful outlook on the future.

There are thus three elements to the concealed counter-narrative of the Exodus: a change of identity, the need for time and the motivation of chessed. These three play a part in the construction of Sacks' understanding of hope but something is still missing. For Sacks hope is not a naïve invitation to a better world in the midst of radical uncertainty. Hope is a process of transformation that is constantly in danger of being undermined by despair, pure self-interest, parochial altruism, fear, doubt, rebellions, and false turns. It can never be taken for granted. It can both develop and degrade. According to Sacks it stands in need of a key institutional support which, for him, is the Sabbath. It is the key to the concealed counter-narrative of the Exodus.

The presence of the Sabbath '... looms large in the book. It was the first commandment the Israelites received in the wilderness. It holds a pivotal place in the ten commandments. It is repeated immediately before and after the episode of the Golden Calf. It is central to the politics of freedom'. ${ }^{33}$ Sacks emphasises how the Sabbath is not only a religious institution, but also, and

30 Jonathan Sacks, The Politics of Hope (London: Jonathan Cape, 1997), p. 259.

31 Sacks, 'The Politics of Hope', p. 63.

32 Sacks, 'The Great Partnership', p. 164.

33 Sacks, 'Covenant \& Conversation, Exodus', p. 16. 
essentially, a 'political' institution. ${ }^{34}$ The case could be made for it being a public rather a political institution: the Sabbath is not about politics in particular but, rather, the wider public sphere.

The way in which Sacks understands the Sabbath possesses four meanings which are of relevance for the problems posed by radical uncertainty. The first is the claim that the Sabbath can be seen as Utopia Now. After Egypt, the first mark of the free people of Israel was the installation of the Sabbath. After Egypt, no Israelite was allowed to see himself/herself any longer as a slave. He or she might be reduced to slavery for a period of time, but this condition of being was a passing plight, not a matter of identity. The Sabbath became the antithesis of Egypt. The Sabbath is a rehearsed utopia that breaks into the present, upending its logic, defying its priorities. Sacks calls this rehearsed practice 'Utopia Now'. ${ }^{35}$ The Sabbath is practising, contemplating and enacting the promised land of freedom, while being on the way.

Sacks then argues that the Sabbath is a neutral space. The idea of neutral spaces is that they have the possibility to bridge differences. They bring people together who would not otherwise meet. Although the Sabbath is public, it is free of one dominant ideology. The Sabbath directs people to something beyond ideology. The Sabbath stimulates a willingness to listen respectfully to those with whom one disagrees. What is more, the Sabbath values the dignity of differences. The reason for this is that only the experience of sharing a common world with others who look at it from different perspectives enables an individual to become aware of one's own identity and opens up to the possibility of developing an alternative new and common identity.

Sacks further assumes that the Sabbath protects and strengthens chessed. It allows the chessed space to inspire, step by step, a new and common identity. The motivation of chessed can never be taken for granted, however. In the midst of radical uncertainty it can easily be lost. The Sabbath is what it literally means - that is, 'to stop' the activities of daily life, not through laziness, but through a call to become creative and inspired again by chessed. It is indeed he driving force behind a new inclusive identity.

Finally, Sacks conceives the Sabbath to be an embodied truth. The Sabbath brings in the power of symbol, music, memory, narrative, poetry, prayer, ritual, art and imagination in order to shape identity and to refer to realities that cannot be expressed in reflections and arguments.

34 Jonathan Sacks, A Letter in the Scroll: Understanding Our Jewish Identity and Exploring the Legacy of the World's Oldest Religion (New York: Free Press, 200o), p. 136.

Sacks, 'Covenant \& Conversation, Exodus', p. 16. 
It is one thing to have an abstract conception of ecological responsibility, another to celebrate the Sabbath weekly ... Prayer, ritual and narrative are ways to shape what De Tocqueville called the 'habits of the heart'. They form character, create behavioural dispositions and educate us in patterns of self-restraint. ${ }^{36}$

In order to make the connection between his readings of hope and the Sabbath with climate change there is some hermeneutical work to be done. The first step is to recognize what kind of literary genre the books of the Torah, including Exodus, comprise. For Sacks the Torah should not be seen primarily in terms of history, legend, chronicle or myth. It is not designed to answer the question: how did the universe come into being? The Torah should be understood as instruction, teaching or guidance. In the context of radical uncertainty, the Exodus sheds a particular light on reality, namely one of hope with a set of underlying assumptions. For Sacks this understanding of hope is not limited to Judaism. Sacks considers hope to be a particular message thematized by Judaism, but available for all. ${ }^{37} \mathrm{He}$ uses several phrases to describe this message of hope, most notably, the 'ethics of responsibility', the 'politics of hope' and the 'political theory of society'.

Through its multiple retellings the Exodus story has become engrained in western societies. ${ }^{38}$ Sacks, indeed, reckons it to be the meta-narrative of hope in western civilization. In several of his writings he has sought to formulate a perspective of hope on contemporary questions. He has only lightly touched upon climate change. ${ }^{39}$ The link between Sacks, hope, the Sabbath, radical uncertainty and climate change thus becomes more indirect. It has been the responsibility of several scientists to make use of yet another retelling of the Exodus story in a time of climate change. Ted Nordhaus and Michael Shellenberger do so indirectly in their essay The Death of Environmentalism (2004). They do so because they believe that climate change requires a more radical reframing than past environmental issues such as acid rain. Ronald

\footnotetext{
36 Sacks, 'Covenant \& Conversation, Exodus', p. 171.

37 Sacks, 'Future Tense', p. 7.

38 Ibid., p. 15 .

39 See, for example, Jonathan Sacks, To Heal a Fractured World: The Ethics of Responsibility (New York: Schocken Books, 2005), p. 7.
} 
Heifetz is more direct. ${ }^{40}$ Even though Sacks' own writing on climate change is limited, the principles to do with hope which emerge from his reading of Exodus can become helpful.

Sacks' understanding of hope presumes that radical uncertainty in the face of climate change cannot be embraced without a change in individual and collective identity. Climate change can no longer be seen as something external and objective to human beings. One of the criteria of hope is that it expects a transformative response to the emergency that comes from within. Such a response happens in two stages. The first is based on the identity underlying the actions that have caused and compound the problem. During that stage it is impossible to formulate exactly the issue at stake, because a person's identity is a part of the problem. If there is no next stage-if this position remains the limit of engagement - then the potential of a hopeful response is stalled. Sacks' second stage orients us to an identity of subjects, which is no longer based on a shared past. Its accent does not fall upon who people are, but on who people want to be. This second stage points to a new and common 'we' that includes those still excluded.

The transformative response to climate change developed above deepens the more common invocations of mitigation and adaptation. Mitigation is about limiting and reducing the greenhouse gas emission (GHG). Because climate change will continue even when these emissions can be limited, there is also the necessity of adaptation. Its focus is on reducing the impact of and vulnerability to climate change by making adjustments to the tangible world. An example from the Netherlands would be the building of higher dikes. A transformative response should not be seen as the opposite or alternative to these commonly recognized approaches: it deepens them with questions of meaning: Who are we as individuals and collective and who do we want to become in relation to ourselves and one another? ${ }^{41}$

40 Jonathan Sacks, Lessons in Leadership: A Weekly Reading of the Jewish Bible (Jerusalem: Maggid Books, 2015), p. xviii.

41 Within the scientific community it is increasingly argued that climate change cannot be solved without a change of identity. See, for example, Gwyn Prins and Steve Rayner, The Wrong Trousers: Radically Rethinking Climate Policy, Institute for Science, Innovation and Society (Oxford: James Martin Institute for Science and Civilization, 2007); Gwyn Prins et al., The Hartwell Paper: A New Direction for Climate Policy after the Crash of 2009 (London: Institute for Science, Innovation \& Society, University of Oxford; LSE Mackinder 
Sacks' understanding of hope presumes that a proper change of identity for all involved needs time. If this is indeed the case a proper response to climate change cannot consist only of the top-down and external market solutions (caps and trade) and government interferences (taxes, regulations and subsidies). Step by step people must change their internal identity: it is thus a bottom-up process. This change cannot be realized within a few years, because it takes time to change the images people live by. The Exodus narrative suggests that such a change requires a journey of small steps with a focus on the present instead of great utopian visions set somewhere in 2050 or 2100.

So much then depends upon chessed being the driving force of this new identity. It arguably becomes visible when two or more people together take responsibility for a shared future in the midst of this radical uncertainty. There are numerous local initiatives for sustainable energy set up by and intended for citizens that serve as an example of such. In Sacks' way of comprehending hope the emphasis is on creating meaning between people with different, even conflicting, interests or viewpoints. An illustration of such would be a director of an environmental NGO and the CEO of an oil company taking responsibility together for a shared, but radically unknown future. Chessed does not seek the affirmation of one specific position: it stimulates opposition in order to open up the identities people live by. An identity that was useful in the past may not still be useful in response to climate change. One of the great achievements of the United Nations' Climate conference in Paris (2015) is the attention given to a more bottom-up approach with the involvement of non-state actors, in other words a civil society.

Programme, London School of Economics and Political Science, 2010), p. 15.; G. Cornelis van Kooten, Climate Change, Climate Science and Economics: Prospects for an Alternative Energy Future (Dordrecht/Heidelberg/New York/London: Springer, 2013), p. 270.; Erik Borgman, Overlopen naar de Barbaren. Het publieke belang van religie en Christendom (Kampen: Erik Borgman \& Uitgeverij Klement, 2009), p. 156.; Karen O’Brien, 'The Courage to Change: Adaptation from the Inside-out', in Susanne C. Moser and Maxwell T. Boykoff, eds, Successful Adaptation to Climate Change: Linking Science and Policy in a Rapidly Changing World (London/New York: Routledge, 2013), pp. 306-19, pp. 306-7. Beyond the scientific community Pope Francis has stated that many things need to change, but that it is '... we human beings above all who need to change', Pope Francis, Laudato Si': On Care for Our Common Home (London: The Incorporated Catholic Truth Society, 2015), no. 202. Pope Francis echoes the words of Ecumenical Patriarch Bartholomew, who has expressed the same publicly. See, for example Patriarch Bartholomew, 'The Quasimodo Lecture 2014', in Jan Jorrit Hasselaar and Peter-Ben Smit, eds, An Ongoing Conversation: The Green Patriarch in the Netherlands (Amersfoort: The Old Catholic Church of the Netherlands, 2015), pp. $48-55$ at p. 55 . 
This Hebrew value of chessed challenges the imagination to create a new 'we' that transcends humanity. This 'we' can now refer to humans and nonhumans who share this creaturely experience on Earth. One instance of this way of seeing things can be found in a report of the second Delta Committee in the Netherlands (2007-2008) where there is a recognition of human agents 'working together with water'. The Delta committee was set up as a way of proactively adapting to climate change and anticipating predicted sea level rise and greater fluctuations in river discharge. In the Committee's view 'attempts to manage nature will continually demand more (and more expensive) efforts.' ${ }^{42}$ The Committee proposed building and developing the country as far as possible in harmony with ecological processes. This approach of working together with water challenges the earlier approach of managing nature. It could, of course, be argued that concepts like 'working together with water' or 'working together with nature' still advocate too instrumental an approach to nonhumans.

The idea of extending chessed to nonhuman beings might be even better expressed in studies of a new field defined by Frans de Waal as evolutionary cognition. This area of research represents 'the study of all cognition (human and animal) from an evolutionary standpoint'. ${ }^{43}$ It is evidently a field of study that rests on a less anthropocentric footing. Evolutionary cognition seeks to treat every species on its own terms. It makes use of human empathy as a way to understand other species. For de Waal ' $[t]$ rue empathy is not self-focused but other-orientated. Instead of making humanity the measure of all things, we need to evaluate other species by what they are. In doing so, I am sure we will discover many magic wells, including some as yet beyond our imagination.' ${ }^{4}$

This reading of evolutionary cognition and chessed can now be seen in the light of Frank Biermann's call for more imagination and courage in order to improve the architecture of the governance of the Earth System. ${ }^{45}$ Biermann's own work is on strengthening (top-down) intergovernmental decision-making. It can stand as such in some degree of tension with Sacks' idea of the Sabbath being a public institution that improves the governance from bottom-up. This

42 Deltacommissie, 'Working Together with Water: A Living Land Builds for its Future', (2008), <http://www.deltacommissie.com/doc/deltareport_full.pdf>, [accessed 28 November 2018], 39 .

Frans B.M. de Waal, Are We Smart Enough to Know How Smart Animals Are? (New York: W.W. Norton \& Company, 2016), p. 28.

44 Ibid., p. 275 .

45 Frank Biermann, World Politics in the Anthropocene (Cambridge: The MIT Press, 2014), p. 203. 
public Sabbath is a regular moment in a transformative response that celebrates the new 'we' in the present. It sets before humanity a new reality-the Sabbath as utopia-rather than allowing the species to be defined by climate change and the imminent requiem of the species. The Sabbath itself becomes a space where differing identities are valued. The Sabbath is not primarily a dispute about who is right: it is a public institution that provides for a disciplined act of communicating (making views intelligible to others who do not share them), and for listening (that is, entering the world of another and thus a role reversal). The Sabbath thus provides a means for protecting and strengthening the relations established in and through chessed. It does so because initiatives in responding to climate change are never immune to setbacks like a disappointing climate summit in Copenhagen or the United States withdrawing from the Paris Agreement: there is much scope for despair, opportunistic behaviour, feelings of fear, futility or scepticism. It can become as such also a site of resistance. It can do so because the Sabbath is an embodied truth. Its mode of meaning-making is not confined to reflection and practical steps forward: the sabbath can also draw upon the power of music, poetry, prayer, art and the faculty of imagination. It sits well with Timothy Radcliffe's belief that the power of music is able to express hope in the midst of radical uncertainty. The playing of music possesses the ability to imagine a different reality other than the present one, and by doing so starting to make this reality real. ${ }^{46}$

Sebastian Kim has warned that 'the danger' of (public) theology is that it is done in academic circles exclusively. It should be done more properly in a mode of interaction with the church, faith communities and the wider society. ${ }^{47}$ What would a re-invention of the Sabbath as essential public institution for all involved in the context of climate change, then, look like? One possible example is the model of the InspirationTable held in the Netherlands prior to the United Nations Climate Change Conference in Paris. ${ }^{48}$

This event was held in the dunes near the North Sea beach of The Hague. There, with an eye to the rising sea level, work is underway to increase the height of the dikes by using new ideas like 'working together with nature'. The Table was organized by churches in the Netherlands. The Table was a neutral space in the public domain, facilitating an honest conversation to do with motives, dilemmas and interests in the setting of the deepening climate

46 Timothy Radcliffe, Timothy Radcliffe on Hope (2017), <http://www.ecldf.net/2017/10/o7/ timothy-radcliffe-on-hope/> [accessed 28 November 2018].

47 Sebastian C. H. Kim, Theology in the Public Sphere (London: sсм Press, 2011), p. 19.

48 See Jan Jorrit Hasselaar, ed, 'We have a dream: InspiratieTafel klimaatverandering: An ongoing conversation' (Amersfoort: The Old Catholic Church of the Netherlands, 2016). 
emergency. The Table brought together students and high-profile representatives from business, religions (Judaism, Islam, Christianity), politicians, NGOs, science and media. Among the representatives were the Dutch Climate Envoy and senior representatives of Rabobank, KPN, CNG Net, ${ }^{49}$ Royal Dutch Shell, Tata Steel, Dunea, Hivos, TEAR and Natuur \& Milieu. All were invited on equal terms. The diversity among the participants was considered to be a resource to create value, rather than a source of clash. The InspirationTable was a smallscale event that aimed to create an atmosphere of trust and interaction. The Table started with an 'iconoclastic fury' to stimulate face-to-face encounters instead of getting mired down in (enemy) images peoples have of each other. In terms of exemplifying the Sabbath as a tutorial of ecological consciousness, the Table was structured around the Papal encyclical Laudato Si' and a video message by Patriarch Bartholomew. The participants went on excursions together: one was into the dunes and another was designed to investigate issues surrounding drinking water. The Sabbath was being enacted as embodied truth. There was music and the sharing of food. The InspirationTable was thus a semiclosed attempt to find the right balance between maintaining an atmosphere of trust, reflection and interacting while publicizing the message and content of the Table. That same evening information about the InspirationTable was shared in a plenary session of the Dutch Lower House. The next morning its aims and message were presented on NPO Radio 1, a public-service radio channel in the Netherlands.

\section{8}

\section{The Hopeful Sabbath}

The concern for the well-being of creation in a time of climate change is a major public issue. It is one in which the dimension of radical uncertainty comes especially to the fore. It is into this uncertain future prospect that Sacks' understanding of hope is inserted. His particular reading of the Exodus narrative and his privileging of the Sabbath does not stand in isolation. It is one part of a much larger body of theological literature. It fulfils a number of functions.

In his God in Creation, Moltmann, for example, argued that the best wisdom about creation 'is to be found in the Jewish theology and practice of the Sabbath. In abandoning the Sabbath, the Gentile Christian churches have lost this means of access, and we generally overlook it altogether, ${ }^{\prime 0}$ In his The

49 Since 2016 CNG Net is part of the company PitPoint clean fuels.

50 Jürgen Moltmann, God in Creation: A New Theology of Creation and the Spirit of God (Minneapolis: Fortress Press, 1985), p. xv. 
Environment and Christian Ethics (1996) Michael Northcott also emphasized that a renewed examination of the Sabbath of the land discloses how humans are not the ultimate owners of the land. The land belongs to God.51

Celia Deane-Drummond supports a role for the 'keeping the Sabbath' in her Eco-Theology. ${ }^{52}$ One of the key elements of the Sabbath is indeed letting creation be: living from the Sabbath, the Lord's Day, leads to a transformation of every day in the week. Deane-Drummond is willing to acknowledge the blessing of the Sabbath for the human community as a whole; her focus, nevertheless, is especially on interweaving the Sabbath into Christian teaching and practice. In a similar vein George Browning, in his Sabbath and the Common Good has examined the Sabbath as a principle for ethical and theological reflection for a Christian response to environmental issues. ${ }^{53}$ Browning's work is partly a response to the call of the Lambeth Conference, the decennial assembly of bishops of the Anglican Communion convened by the Archbishop of Canterbury, in 1998 and 2008 for a 'recovery of the 'sabbath principle' and the development of a sabbath theology in order that the Church may more adequately respond to the environmental crisis. ${ }^{54}$

Sacks' understanding of hope is a perspective on radical uncertainty in the context of climate change which is already available. It is not a naïve invitation to a better world. It recognises despair, sheer self-interest and false turns. For it to fulfil its potential, it requires something like a public Sabbath appropriately conceived on different scales and in different contexts. This Sabbath consists of contemplative dimensions, but is also action oriented. It accentuates, therefore, a dimension of action within what Borgman calls a politics of contemplation. With his politics of contemplation Borgman is arguing against a too activist approach in policies. By doing so, he does not aim to create a tension between a contemplative and an action-oriented approach to hope. Nevertheless, to avoid misunderstanding, I prefer to speak of a politics of contemplation and action. The practices of the public Sabbath should not be seen as religious side-events at a climate conference. They are not a religious event in the margins. The Sabbath is a public institution that embraces hope, the possibility of transformative change, the renewal of identity and embodied action. It does so in the service of the creaturely existence of humans and nonhumans living on a planet in peril in a time of climate emergency.

\footnotetext{
51 Michael Northcott, The Environment and Christian Ethics (Cambridge: Cambridge University Press, 1996), p. 187.

52 Celia Deane-Drummond, Eco-Theology (London: Darton, Longman and Todd Ltd, 2008), p. 181.

53 George Victor Browning, Sabbath and the Common Good: Prospects for a New Humanity (Melbourne: Echo Books, 2016), p. 255. 